\title{
A Postmodern Defence of Universal Liberal Legal Norms
}

\author{
Lisa M. Austin
}

Version Post-print/accepted manuscript

Citation Lisa Austin, "A Postmodern Defence of Universal Liberal Legal

(published version) Norms" (2010) 23:1 Canadian Journal of Law and Jurisprudence 23.

Publisher's Statement Lisa Austin, "A Postmodern Defence of Universal Liberal Legal

Norms" (2010) 23:1 Canadian Journal of Law and Jurisprudence 23.

Reprinted by permission of Cambridge University Press.

https://doi.org/10.1017/s0841820900004793

\section{How to cite TSpace items}

Always cite the published version, so the author(s) will receive recognition through services that track citation counts, e.g. Scopus. If you need to cite the page number of the author manuscript from TSpace because you cannot access the published version, then cite the TSpace version in addition to the published version using the permanent URI (handle) found on the record page.

This article was made openly accessible by $U$ of $T$ Faculty. Please tell us how this access benefits you. Your story matters. 


\title{
A POSTMODERN DEFENCE OF UNIVERSAL LIBERAL LEGAL NORMS•
}

\author{
Lisa M. Austin \\ Published in: (2010) 23 Can JL \& Jur 5
}

\section{Introduction}

Law is centrally concerned with norms and liberal legal theory with universal norms that apply to all individuals within society. Nonetheless, there is a current of "norm anxiety" that runs through liberal legal theory, periodically surfacing in various guises. For example, the debate regarding the indeterminacy of legal norms in part questions the ability of such norms to regulate human behaviour if they cannot lead to reliable and determinate outcomes in their application. ${ }^{1}$ The same current of thought can also implicate the status and legitimacy of the law: if legal indeterminacy permits, or even requires, an unbounded exercise of discretion on the part of judges, it blurs the line between law and politics and turns judges into illegitimate legislators. ${ }^{2}$ Others have argued that legal norms, even if regulative of behaviour, may fail to cohere with an acceptable public justification for the use of force involved in their application, thus rendering any connection to justice, or distinction from the exercise of political power, tenuous. ${ }^{3}$ For example, some have claimed that legal norms merely institutionalize and

\footnotetext{
- I would like to thank Robert Gibbs, David Dyzenhaus, Arthur Ripstein and Joe Murray for their many thoughtful comments on earlier versions of this work. Some of the arguments regarding Levinas were presented at the Centennial Conference on Levinas and Law (McGill University Faculty of Law, 2006) and benefited from discussion with the conference participants.

${ }^{1}$ See e.g. realists such as Felix Cohen, "Transcendental Nonsense and the Functional Approach" (1935) Columbia Law Review 809.

${ }^{2}$ For e.g., this is one of the motivations for Dworkin's account of the law as integrity in Law's Empire (Cambridge, Massachusetts: Harvard University Press, 1986).

${ }^{3}$ See e.g., Critical Legal Studies proponents such as Duncan Kennedy, A Critique of Adjudication (fine de siècle) (Cambridge, Mass.: Harvard University Press, 1997).
} 
conceal oppressive power structures in the guise of neutrality; ${ }^{4}$ others debate the legitimacy of imposing certain versions of liberal individual rights on members of religious or cultural minorities who reject that they are universal values. ${ }^{5}$

The standard responses to norm anxiety are familiar. They include denial, or at least containment, as in the case of appeals to features "internal" to the institutionalized practice of law ${ }^{6}$ or on process rather than substance. ${ }^{7}$ Others embrace this anxiety in a variety of ways, endorsing "more pluralistic, contextual, and nonessential explanation of law and legal decisionmaking developed for a multicultural society" ${ }^{\prime 2}$ including, at its extreme, the explicit realignment of law with politics ${ }^{9}$.

This paper will offer a fundamentally different response, rooted in the work of the French philosopher Emmanuel Levinas. Although he himself says relatively little regarding law, his account of justice provides an important set of resources for thinking about universal liberal legal norms and legal reasoning about these norms. This is due to his responses to two important sources of norm anxiety. One major source is contemporary pluralistic and multicultural democracies which make the variability of norms so practically apparent. This familiar feature of modern life feeds into another

\footnotetext{
${ }^{4}$ There are many feminist arguments of this natures. See e.g. Catharine A. MacKinnon, "Feminism, Marxism, Method, and the State: Toward Feminist Jurisprudence" (1983) 8 Signs: Journal of Women in Culture and Society 635.

${ }^{5}$ For a discussion of the relationship between Shari'a and its relationship to the liberal state, see Anver Emon, "Islamic Law and the Canadian Mosaic: Politics, Jurisprudence and Multicultural Accommodation" in Legal Consciousness, eds. Leonard Kaplan and David Weisstub (forthcoming)

${ }^{6}$ See e.g., Ernest J. Weinrib's formalist account of private law's “internal” unifying structure in The Idea of Private Law (Cambridge, Mass.: Harvard University Press, 1995).

${ }^{7}$ See e.g., John Hart Ely, Democracy and Distrust: A Theory of Judicial Review (Cambridge, Mass.: Harvard University Press, 1980). For an application of this in the Canadian constitutional context, see Patrick J. Monahan, "Judicial Review and Democracy: A Theory of Judicial Review" (1987) 21 University of British Columbia Law Review 87.

${ }^{8}$ Gray Minda argues that this describes jurisprudential movements as diverse as Law and Economics, Critical Legal Studies, Feminist Legal Theory, Law and Literature and Critical Race Theory. See Gary Minda, Postmodern Legal Movements (New York: New York University Press, 1995) at 2.

${ }^{9}$ Allan C. Hutchinson, It's All in the Game: A Nonfoundationalist Account of Law and Adjudication (Durham, N.C.: Duke University Press, 2000)
} 
major source of norm anxiety, which is an intellectual climate suspicious of the claims of universal values. Levinas addresses this second source through his engagement with the work of German philosopher Martin Heidegger. Heidegger provides one of the most sustained and sophisticated philosophical versions of this suspicion with his account of the social embeddedness of the self and his argument from this idea of the self to the ultimate contingency and groundlessness of any claims of normativity. Levinas' response to Heidegger allows him to address the first important source of norm anxiety as well, for Levinas rescues the central place of norms within a theory that nonetheless takes as its starting point the radical plurality of society and retains a strong sense of the social nature of meaning.

This paper will first outline the main elements of Heidegger's influential version of what I have been calling "norm anxiety" as well as how this leads to a number of difficulties in relation to the liberal-democratic ideal of law. Then I will situate Levinas in relation to Heidegger in order to outline more precisely why he offers such a complex, and nuanced, response to this anxiety. Levinas has had virtually no reception in legal theory, except via his influence on Derrida's project of deconstruction. ${ }^{10}$ In presenting Levinas in his own terms, and in terms of his response to Heidegger, I hope to show that Levinas in fact rescues a sense of the human that is not conditioned by cultural context and which can provide the basis for an understanding of justice that is more normative than theorists like Derrida have allowed. Indeed, I will argue that Levinas provides us with the basis of affirming universal values such as human rights, as well as norms such as freedom, equality and dignity. At the same time, Levinas does not require us to throw away some of the central insights of Heidegger regarding the deeply social and

\footnotetext{
${ }^{10}$ See e.g. Drucilla Cornell, The Philosophy of the Limit (Routledge, New York, 1992).
} 
contextual nature of meaning. If there is a significance to the human beyond the particular context in which we find ourselves embedded, and which can justify the endorsement of liberal-democratic norms, the expression of this remains essentially culturally conditioned and requires ongoing debate and revision. This, I will argue, leads to a view of legal norms as inseparable from the practice of reasoning about these norms. Far from radical, the result should be surprisingly familiar to lawyers - for I will argue that this is in fact what common law reasoning looks like.

\section{Heidegger's Norm Anxiety and Liberal Legal Norms}

The liberal-democratic ideal of law is centrally concerned with the public nature of law. "Public" here does not refer to the general area of law that regulates public institutions, in contrast to that which regulates private interactions. Rather, "public" refers to a set of concerns that are taken to mark out the exercise of legal authority as distinct from, and regulative of, the exercise of political authority. This encompasses the idea that laws are of general application (apply to the public) rather than individualized and arbitrary acts of state coercion, they are known in advance (are public rather than secret), and are seen to be legitimate (have a public justification). Thicker liberal-democratic notions of law also focus on a second concern, that of vindicating a particular understanding of human freedom within the public realm, understood in terms of both the relationship between the individual and the state and the relationship between individuals. This second concern is connected to the first: understandings of individual freedom inform the precise understanding of the various dimensions of the "public" nature of law. 
In the following section I will outline Heidegger's version of "norm anxiety" and show how it leads to a number of tensions with respect to the liberal democratic ideal of law: at best, liberal legal norms should be understood as historically contingent practices rather than properly regulative justifications for the exercise of authority; at worst, liberal legal norms impede the project of individual authenticity and freedom as Heidegger understands it.

\section{(a) The Heideggerian Self}

It has become almost trite in some academic circles to talk of the deeply constitutive nature of one's social and cultural context although there are many different versions of such contextual selves. In Being and Time, Heidegger's account of "Dasein"_-Heidegger's invented term for a human being — provides one of the earliest, and most influential, philosophical versions of such a socially embedded self. ${ }^{11}$ Indeed, Dasein is offered as a critique of the Kantian subject and is deeply connected to Heidegger's view of the ultimate historical contingency and groundlessness of claims of normativity. As such Heidegger's account of the self and the challenges it poses to liberal democratic norms should interest any legal theorist who seeks to either embrace, or respond to, an embedded self.

In German "Dasein" translates literally as "there-being". Heidegger creates this term for a human being in order to reflect what for him is basic to being human: Dasein is always preceded by its "there." What this means is that humans always already exist

\footnotetext{
${ }^{11}$ Martin Heidegger, Being and Time, trans. by Joan Stambaugh (Albany, New York: State University of New York Press, 1996).
} 
within an implicit understanding of the world, or horizon of meaningfulness. Heidgger calls this "Being" but we can avoid his philosophical language and roughly approximate his meaning by replacing this with "cultural understanding" so long as we view "culture" in extremely broad terms to mean something like a comprehensive world view. ${ }^{12}$ What Heidegger argues is that we do not explicitly adopt this world view but are already within it when we try to do or understand anything in our lives.

The first important implication of this embeddedness is that the idea of "subjects" who act in and on a world of "objects" crucially misunderstands the nature of what it is to be human. Heidegger argues that our primary reality is in fact the average everyday world in which Dasein is absorbed in the handling, using and taking care of things. Its underlying structure is not characterized by abstract subjects and objects but by Dasein's practical engagement within an already existing implicit understanding of the world. This is Heidegger's “being-in-the-world."

Perhaps Heidegger's most famous illustration of this is his example of a hammer. ${ }^{13}$ A hammer is "something in order to" and we encounter it as a useful thing in using it. In fact, it is most useful precisely when we no longer notice it but use it. It is "ready-to-hand" but not something contemplated in itself. Our everyday being-in-theworld, however, is not concerned with tools per se, but with work. Work is the "what-

\footnotetext{
${ }^{12}$ In fact, Heidegger's central goal in this work is to uncover the underlying structure of the preunderstanding of Dasein in order to lay the proper groundwork for an inquiry into Being itself. For Heidegger, Dasein "always understands itself in terms of its existence, in terms of its possibility to be itself or not to be itself." (Ibid. at 10). In asking the question of Being, therefore, Dasein already stands within an understanding of Being and also understands itself in relation to Being, at least in terms of this implicit understanding. The entry point into the question of Being is therefore Dasein and Dasein's average everyday understanding of the world. This is the difference between the "ontic" and the "ontological" as it operates throughout Being and Time. The "ontic" is the realm of average everydayness and the "ontological" is the underlying structure of this realm. Because this language is so specialized, often obscure, and lies far outside most legal debates, I have avoided using it in the main body of this article.

${ }^{13} \mathrm{Ibid}$. at $64 \mathrm{ff}$.
} 
for" of the hammer, and is itself a useful thing, as when "[t]he shoe to be produced is for wearing (footgear), the clock is made for telling time." But the production process itself makes references to the materials of the work, as production is "a using of something for something." These materials in turn make reference to animals and nature, which are not themselves produced but are "always already at hand." Work also points to the wearer and user of the product, the particular or only average people for whom the work becomes handy, which in turn points to the world in which we live. Ultimately these references take their meaning from the particular understanding of the world to which Dasein is always already related and which gives shape to his or her life projects.

Absorbed in practical engagement with the world in this way, Dasein does not primarily encounter "things" at all, but uses them in the context of various life projects. Things, like hammers, only become conspicuous to Dasein in situations of breakdown, when what is ready-at-hand becomes unusable, or goes missing. However, even in this context it is disclosed as a useful thing. Indeed, it is at such times that the set of constitutive references outlined above come to the attention of Dasein and Dasein has the opportunity to understand what the hammer "is" - that it is related to work, the world, and Dasein's projects. However, when such a useful thing becomes an object of a statement, then it becomes something "about which" a statement is made and its nature is obscured; instead of a tool, related to the meaningful context of Dasein's world, it is an abstract object to which useful properties and relationships must then be posited as additions. In other words, for Heidegger any talk of a "subject" encountering an "object" is derivative of the more fundamental reality of practical engagement and, significantly, helps to veil this reality. 
Similarly, for Heidegger the idea of an abstract "subject" is in fact derived from our more primary average everyday experience of collectivity that he calls "being-with." Or, as Heidegger puts it: "the world is always already the one that I share with the

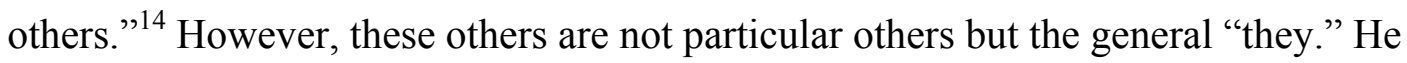
argues:

In utilizing public transportation, in the use of information services such as the newspaper, every other is like the next. This being-with-one-another dissolves one's own Da-sein completely into the kind of being of "the others" in such a way that the others, as distinguishable and explicit, disappear more and more. In this inconspicuousness and unascertainability, the they unfolds its true dictatorship. We enjoy ourselves and have fun the way they enjoy themselves. We read, see, and judge literature and art the way they see and judge. But we also withdraw from the "great mass" the way they withdraw, we find "shocking" what they find shocking. The they, which is nothing definite and which all are, though not as a sum, prescribes the kind of being of everydayness. ${ }^{15}$

Heidegger's claim is not primarily that Dasein is immersed in the social world as a kind of interchangeable self. Importantly, he also argues that "the they prescribes the nearest interpretation of the world and of being-in-the-world." ${ }^{16}$ That is, it is the public realm that provides the constitutive set of references that forms the pre-understanding that characterizes the average everyday existence of Dasein. This context of meaningfulness, while often explicitly articulated in terms of what "one" should think, say, or do, is largely implicit, forming a backdrop of familiarity and relevance that allows things within Dasein's world to appear as they do. In other words, the implicit cultural understanding or world view that Dasein is always already related to, and which forms the core of Dasein's own understanding of self, is given by the public realm.

\footnotetext{
${ }^{14} \mathrm{Ibid}$. at 111.

${ }^{15} \mathrm{Ibid}$. at $118-9$.

${ }^{16} \mathrm{Ibid}$. at 121.
} 
If the idea of an abstract "subject" is to be understood as derivative of a more primary being-with, then the primary issue with respect to the relationship between the subject and different conceptions of the social sphere is not to determine how a pre-given "I" can and should interact with others. Rather, the primary issue is how anyone becomes an "I" at all. In other words, for Heidegger the "I" is not a given, but something that must be achieved. The task is to relate to one's understanding of the world and self in a manner that is not simply pre-given by the public realm and unreflectively absorbed but is actively taken up from the historically contingent possibilities in which we already find ourselves. This, for Heidegger, is the question of authenticity, or the sense in which Dasein's relationship to its own understanding and possibilities is "mine."

While the Heideggerian concept of authenticity is complex and cannot be fully explicated here, there are a few features that are important for the arguments in the rest of this paper. For Heidegger, authenticity involves a certain relationship with temporality, for time is "the horizon of every understanding and interpretation of being.",17 Authenticity is therefore not about expressing one's "inner" self but instead refers to a relationship with one's cultural understanding and possibilities, which becomes a relationship with temporality, or coming to terms with one's own finitude. Moreover, just as the breakdown of the hammer can provide Dasein with an understanding of the world of work, it is death, anxiety, and the call of conscience that can pull Dasein out of an "entangled absorption" in the public world and propel Dasein toward authenticity. Death because it individuates Dasein, anxiety because it reveals the ultimate groundlessness of any particular context of meaning, and the call of conscience because it is silent and as

\footnotetext{
${ }^{17} \mathrm{Ibid}$. at 15 .
} 
such represents the possibility of not listening to the "they." 18 It is this last feature - the necessity that the call of conscience be silent - that is important with respect to the connection between authenticity and language, at least within the framework of Being and Time, for it points to the irredeemably inauthentic nature of public discourse. It is inauthentic because the discourse of the public realm is intrinsically tied to the veiling of Dasein's relation to his cultural context and requires silencing. It is irredeemably so because this is, for Heidegger, part of the human condition and not something that can change through a different cultural configuration of the public realm. ${ }^{19}$

The later Heidegger drops the language of authenticity but retains his concern to articulate the terms of what he comes to call Dasein's "free relation" relation to "Being." This understanding of Dasein's freedom maintains many structural similarities with Heidegger's earlier articulation of authenticity. First, he continues to understand Dasein's task in terms of understanding the nature of the way in which a particular cultural understanding, or background of constitutive references, allow things to appear as they do. ${ }^{20}$ Second, although the later Heidegger drops the language of anxiety, he continues to insist on the need for Dasein to appreciate the ultimate groundlessness and temporal

\footnotetext{
${ }^{18}$ Ibid. at 250-251.

${ }^{19}$ For example Heidegger argues that inauthenticity is not to be understood as "a bad and deplorable ontic quality which could perhaps be removed in the advanced stages of human culture" but rather as a fundamental ontological-existential structure of Dasein. Ibid. at 165.

${ }^{20}$ See e.g. Martin Heidegger, "The Question Concerning Technology" in Martin Heidegger: The Question Concerning Technology and Other Essays, trans. by William Lovitt (New York: Harper \& Row, 1977) at 25. Although a full discussion of this shift between Heidegger's early and later works is beyond the scope of this paper, one aspect is focus: from a focus on Dasein as the being for whom Being is a question to the question of Being itself. This shift in focus also includes a shift in the manner in which he discusses Dasein. Much of the highly individualized and active vocabulary characterizing Dasein's authenticity — and which greatly influenced the development of French existentialist philosophy-is dropped in favour of descriptions of Da-sein that treat Da-sein in much more generic and passive terms as the "shepherd of Being," "open" to an advent of Being that is "granted" to it. See Martin Heidegger, "Letter on Humanism" in Martin Heidegger: Basic Writings, $2^{\text {nd }}$, rev. and expanded ed., David Farrell Krell, ed. (New York: HarperCollins, 1993).
} 
specificity of our context of meaning. ${ }^{21}$ Third, Heidegger's concerns regarding inauthenticity become, in his later work, a concern for the "forgetfulness of Being." By this he means a forgetfulness of the way in which we are tied to an already given understanding provided to us by the public realm. The later Heidegger stresses the deeply historical nature of these different public understandings and points particularly to the dominance of the subject of modern metaphysics - the abstract self — as an understanding that obscures the true nature of the self. ${ }^{22}$ Famously, he argues that Gestell, or the particular background of understanding of our modern, technological age, represents the "supreme danger" to humanity because it is characterized by a view of the subject as commanding a world of objects at its disposal rather than a self already embedded within a world, formed by it, and used to maintain its meaning. ${ }^{23}$

In sum, what Heidegger's work first articulated in a penetrating way is that the proper understanding of the relationship between Dasein and what he calls "Being" (and I have been calling our cultural understanding) reveals that our prior social embeddedness in the world is not simply a factual condition (e.g., that we are born into a community that socializes us) but one that is constitutive of us as selves. Moreover, for this relationship to be either "authentic" or "free" requires, in part, a deep appreciation of the historically contingent nature of any world view that we find ourselves situated within. ${ }^{24}$

\footnotetext{
${ }^{21}$ In his later writings, Heidegger points to the different historical characters of what he calls the "revealing" of Being, which has to be understood as separate from the nature of Being itself. See Martin Heidegger, "The Onto-theo-logical Constitution of Metaphysics," in Identity and Difference, trans. By Joan Stambaugh (New York: Harper \& Row, 1969).

${ }^{22}$ Heidegger, "Letter on Humanism," supra note 20 at 221.

${ }^{23}$ Heidegger, "The Question Concerning Technology" supra note 20.

${ }^{24}$ This is not to suggest that this is all that is required. The question of what we are to "do" in order to have a free relation is quite complex and much of his later writings on this point are quite difficult and obscure. For example, Heidegger argues that freedom is "letting beings be" which means "to engage oneself with the open region and its openness into which every being comes to stand, bringing that openness, as it were, along with itself." See "On the Essence of Truth" in Martin Heidegger: Basic Writings, $2^{\text {nd }}$, rev. and
} 


\section{(b) The Question of Norms}

Heidegger's view of the self as absorbed in a world that already provides it with a historically specific context of meaning has a number of implications for legal theory. Some theorists have taken up such an account in order to inform debates regarding the nature of adjudication as an interpretive practice. For example, Balkin argues that "[b]ecause the legal subject is herself socially constructed, we must consider how her social construction leads her to understand the legal system. ${ }^{, 25}$ Similarly, Leiter has argued that Heidegger's account of being-in-the-world can provide insight into how judges make what he calls "relevance" judgments in determining whether a case should be distinguished from the applicable precedent. ${ }^{26}$ Leiter argues, drawing upon Heidegger's understanding of the being-in-the-world of practical engagement, that such relevance judgements depend upon this Heideggerian "background" of practical knowhow and resists theoretical articulation..$^{27}$ The consequences of this, for Leiter, are that if a theory of adjudication fails in achieving a full descriptive articulation then it also fails in its normative ambitions of critical evaluation. ${ }^{28} \mathrm{He}$ argues that this provides an important reason for embracing a more "“naturalized' approach to jurisprudence” which

expanded ed., ed. by David Farrell Krell (New York: HarperCollins, 1993) at 125. In other works, he links this with his retrieval of techne. See "The Question Concerning Technology" supra note 20.

${ }^{25}$ J.L. Balkin, "Understanding Legal Understanding: The Legal Subject and the Problem of Legal Coherence" (1993) 103 Yale L.J. 105 at 107.

${ }^{26}$ Brian Leiter, "Heidegger and the Theory of Adjudication" (1996) Yale L.J. 253 at 260. For a critique of his account of practical reasoning, but still within a Heideggerian framework, see Linda Ross Meyer, "Is Practical Reason Mindless?" (1998) 86 Geo. L.J. 647.

${ }^{27} \mathrm{Ibid}$. at $272 \mathrm{ff}$.

${ }^{28} \mathrm{Ibid}$. at $276 \mathrm{ff}$. 
is more concerned with describing what courts actually do. ${ }^{29}$ Byrne has recently added to this literature by arguing that a Heideggerian account of the self does not necessarily lead to an account of judicial interpretation, that he attributes to Fish, where it is impossible to judge some decisions as better than others. ${ }^{30}$

But what about questions regarding the justification of liberal legal norms themselves, and not simply questions regarding how judges apply such norms to particular cases? Several conclusions are possible. For example, we could argue that although norms are not "objects" they are nonetheless analogous to the abstract "objects" that Heidegger critiques as being derivative of a prior embeddedness. In other words, norms must be understood to express elements of a particular historical context rather than some ahistorical "truth". We could also argue that specific norms, just like specific objects such as Heidegger's hammer, might be useful within the world of practical engagement that is our average everyday experience. However, hammers are useful within the context of the work, the worker, and the broader context of meaning surrounding these. In this way, the "usefulness" of norms cannot escape from the historical contingency of any ultimate criteria for this usefulness. Given these two considerations, legal norms become merely conventional, tied to their particular historical context and radically uprooted from any claims to a kind of ahistorical, universal "ground."

This view leads to a number of tensions in relation to many liberal-democratic understandings of law, particularly when coupled with the fact of contemporary

\footnotetext{
${ }^{29} \mathrm{Ibid}$. at 282.

${ }^{30}$ Gavin Byrne, "The Self and Strong Legal Theory: A Heideggerian Alternative to Fish's Scepticism. Byrne roots this in an interpretation of Heidegger's metaphysical commitments to "natural kinds". Even if this permits him to assert that some interpretations are better than others, this does not affect the arguments of this paper regarding the justifications for legal norms.
} 
multicultural and pluralistic societies where there are many different competing practices, all of which could be said to reflect their particular historical and cultural contexts. One problem is that, in cases of conflicting norms, it is unclear how to generate any criteria of justification for accepting some over others that can claim to be truly normative. Balkin provides a good example:

[w]e might use the commitment to equality expressed in the Civil Rights Act of 1964 to criticize the lack of civil rights for homosexuals in the United States. The question remains, however, why we saw a particular aspect of our cultural practices as a worthy basis for our critique and another aspect as unworthy. Since both are equally aspects of our culture, culture by itself cannot serve as a norm to decide between them. ${ }^{31}$

The skepticism that this engenders clearly raises questions regarding the acceptance of substantive liberal-democratic norms such as universal human rights. However, it also influences the acceptance of the "public" nature of law that characterizes liberaldemocratic understandings. For example, it can call into question the possibility of a public justification for the exercise of political authority that is either distinct from mere politics or has some claim to regulate groups who reject the justification and its purported universality. Many of these claims should be familiar from debates in legal theory regarding non-foundationalism in general and many such accounts would find in Heidegger a great ally_ — and likely already owe him intellectual debt. The most extreme positions in these debates include accounts that equate law with politics and argue that

\footnotetext{
${ }^{31}$ J.M. Balkin, "Transcendental Deconstruction, Transcendent Justice" (1994) 92 Mich. L. Rev. 1131 at 1175. Balkin argues for a version of deconstruction that recognizes that human values transcend culture. As such, his views bear an affinity to the interpretation of Levinas that I offer in this paper. However, Balkin's own project would benefit from an engagement with Levinas, for Levinas is the intellectual source of the "transcendental" moments in Derrida's work that he is interested in and could be used to provide more clarity to the relationship between deconstruction, justice and responsibility.
} 
norms that pass as "universal" or "neutral" more often than not mask the interests of privilege. $^{32}$

I do not want to suggest here that the embrace of Heidegger necessarily entails the embrace of some of these more extreme positions. But I do want to suggest that his view of the socially embedded self at least unsettles some of the commitments that traditionally underpin the liberal-democratic ideal of law, legal norms, and the possibility of public justification for coercive state action. And this raises the question of whether alternative accounts of these commitments can be given that can accommodate the idea of a situated self in a less troubled manner. In this vein, there are two Heideggerian possibilities for justifying liberal-democratic norms that I want to examine. The first is to seek to "ground" norms in his understanding of human freedom by working out its political and legal implications. The second is to "ground" norms in a pragmatic argument for the kind of political and legal institutions that would likely be helpful in securing the conditions for this freedom even if this public realm must itself remain a derivative expression of this understanding of freedom. I will argue below that it is difficult to sustain either strategy on Heideggerian grounds alone.

The first Heideggerian strategy for justifying particular norms over others is to do so in terms of their relationship to his idea of human freedom or what in his earlier work he referred to as authenticity. However it is not clear that authenticity can be the source of norms regulating our interactions with others in the way that the more familiar liberaldemocratic ideas of autonomy and agency can be: authenticity is not about one's interactions with others but about the need to withdraw, in some sense, from these others in order to understand one's own temporality and finitude. This is an individual project,

${ }^{32}$ See e.g., Stanley Fish, The Trouble With Principle (Cambridge, Mass.: Harvard University Press, 1999) 
and although it involves understanding oneself as already existing within a particular historical context, for Heidegger it does not involve any normative claims regarding what the political and legal context should look like.

In fact, Heidegger only made one attempt to describe the state in terms of his view of freedom and that was his account of the polis in Introduction to Metaphysics. ${ }^{33}$ However, this polis bears little resemblance to a liberal-democratic state. One of its defining features is its relationship to what Heidegger describes in terms of "struggle." One aspect of this struggle is the creative act of foundation. The poets, thinkers, priests and rulers of the polis are creators in the sense of opening a world: the founding act of the creators opens a new disclosure of Being, or historical context of meaningfulness, and this founding act is to be understood as a struggle against the existing disclosure. ${ }^{34}$ For this reason, the founding of the state is something that has no measure. ${ }^{35}$ However, the polis also requires ongoing struggle in order to maintain it as something originary and not have it descend into simply another particular context of meaning that then contributes to the obscuring of its own contingency. ${ }^{36}$ Given this, it is difficult to see how for Heidegger such a polis would ever conform to liberal-democratic notions of the rule of law; the idea that political authority should be constrained by normative principles realized through an enduring set of institutions is antithetical to this idea of founding and maintaining the disclosure of originary meaning that has no measure. Moreover, such a polis could never agree with other central liberal-democratic norms such as equality and freedom.

\footnotetext{
${ }^{33}$ Martin Heidegger, Introduction to Metaphysics, trans. by Gregory Fried and Richard Polt (New Haven: Yale University Press, 2000) at 204. See also p. 50 where Heidegger makes reference to "poetry and fine arts, statescraft and religion" and again at p.163 where he places together poets, thinkers, priests and rulers. ${ }^{34}$ Ibid. at 63

35 The poets, thinkers, priests and rulers are "without structure and fittingness ... because they as creators must first ground all this in each case." Ibid. at 163.

${ }^{36} \mathrm{Ibid}$. at 67.
} 
According to Heidegger, struggle implies inequality: the maintenance of the "opening" of this new disclosure of meaning requires rank and dominance, not a "sentimental" suppression of inequality. ${ }^{37}$ Put simply, the polis that Heidegger describes is antithetical to liberal-democratic norms.

After the Second World War, Heidegger retreated from this position and abandoned all reference to the polis. ${ }^{38}$ While this might reflect a change in his understanding of the relevance of the political realm to human freedom, it bears noting that his views regarding the nature of justice, or dike, remain consistent between the writing of Introduction to Metaphysics and his later essay, "The Anaxamander Fragment." ${ }^{39}$ In the latter, Heidegger insists that injustice occurs when what is disclosed in the world in a particular historical context strikes a "willful pose of persistence" aiming for "continuance and subsistence" and therefore concealing its relation to its particular historical context and the contingency that is at its core. ${ }^{40}$ Similarly, in Introduction to Metaphysics, Heidegger argues that any attempt to articulate an ultimate "ground" for the polis simply veils the true nature of Being as that which is outside all questions of justification. ${ }^{41}$ Therefore any sense of the rule of law as involving a set of enduring norms and institutions that regulate and justify the exercise of political authority - especially if these norms affirm universal values - could be said to be more closely linked to the idea of injustice than justice for Heidegger. Indeed, Heidegger could

\footnotetext{
${ }^{37}$ Ibid. at 141 .

${ }^{38}$ There is a large literature on Heidegger's relationship with Nazism. See Victor Farías, Heidegger and Nazism, Philadelphia: Temple University Press, 1989).

${ }^{39}$ Martin Heidegger, "The Anaximander Fragment" in Early Greek Thinking, trans. by David Farrell Krell and Frank A. Capuzzi (San Francisco: Harper \& Row, 1975).

${ }^{40} \mathrm{Ibid}$. at 42.

${ }^{41}$ Heidegger, Introduction to Metaphysics, supra note 33 at 212-213.
} 
argue that states that are not constituted according to the rule of law, even if more violent, might be better from the perspective of the issue Dasein's freedom as he understands it.

If one cannot "ground" liberal-democratic norms in this idea of freedom, then another possibility is to anchor these norms pragmatically. That is, one could argue that they are useful in relation to securing an individual's authenticity, or freedom, even if they will always be derivative of this relationship and cannot guarantee its attainment. This is, indeed, Richard Rorty's strategy when he describes a liberal state where citizens are "liberal ironists", aware of the contingency of their beliefs and their communities but where this irony remains part of the private rather than public sphere. ${ }^{42}$ It is the institutions of bourgeois liberal society, he argues, that have historically proven to best secure the conditions of private irony.

However, Heidegger's critique of modernity strongly suggests that Heidegger would view the liberal-democratic project of law as problematic in relation to securing Dasein's freedom as he understands it, even in this more pragmatic sense.

As outlined earlier, part of Heidegger's analysis of authenticity was to show that the modern understanding of the self in terms of autonomy and agency misunderstands the nature of the public sphere and the role of authenticity in securing the self. Given this, liberal-democratic norms that are rooted in notions of autonomy and agency for Heidegger help to veil what it means to be a self. Of course, all political and legal norms, as part of the public sphere, do this. But the later Heidegger suggests that some cultural and historical configurations of the public sphere are worse than others in this regard:

\footnotetext{
${ }^{42}$ Richard Rorty, Contingency, Irony, and Solidarity (Cambridge: Cambridge University Press, 1989). For Rorty, only the intellectuals would be true ironists, and the nonintellectuals would be "commonsensically nominalist and historicist. So they would see themselves as contingent through and through, without feeling any particular doubts about the contingencies they happened to be." Ibid. at 87.
} 
what he calls the "forgetfulness of Being" becomes particularly dominant and penetrating in some historical periods. ${ }^{43}$ Understood in these terms, it is not clear that liberaldemocratic norms are better than any other political or legal norms in securing the conditions of authenticity and they may in fact be worse.

Indeed, from the perspective of forgetting our true nature as embedded selves, many political distinctions that we liberals would take to be important become inessential. For example, Heidegger argues that "Russia and America, seen metaphysically, are both the same: the same hopeless frenzy of unchained technology and of the rootless organization of the average man."44 Furthermore, in "Memorial Address," he argues that the real danger of the technological age is not the hydrogen bomb and its potential to annihilate life on earth, but rather that "the approaching tide of technological revolution in the atomic age could so captivate, bewitch, dazzle, and beguile man that calculative thinking may someday come to be accepted and practiced as the only way of thinking." ${ }^{45}$ Similarly, given the links that Heidegger makes between this idea of calculative, or technological thinking, and the philosophy of the modern subject that has historically grounded the norms of liberal-democracy, Heidegger could argue that any particular political structure is most dangerous when it keeps its citizens happy, safe, prosperous and under what Heidegger would consider an "illusion" of freedom. For such a regime operates to keep Dasein content with what is readily available and not prepared to question in the manner called for by his "originary" notion of freedom.

\footnotetext{
${ }^{43}$ See Heidegger, "The Question Concerning Technology" and "Letter on Humanism" supra note 20.

44 Heidegger, Introduction to Metaphysics, supra note 33 at 40.

${ }^{45}$ Heidegger, "Memorial Address," in Discourse on Thinking, trans. By John M. Anderson and E. Hans Freund (New York: Harper \& Row, 1966) at 56.
} 
For all of these reasons, Heidegger's understanding of the self and authenticity or freedom do not provide an easy basis, either directly or in a more pragmatic fashion, for endorsing liberal-democratic norms. Instead, we are left with a view of norms as historically contingent features of our social context, with all the resulting tensions for the liberal-democratic view of law already discussed.

Several possibilities for response are available. One could, of course, argue that Heidegger is simply wrong in suggesting that liberal norms are problematic and create an account of how liberal values can indeed secure the conditions for a kind of Heideggerian authenticity or freedom. ${ }^{46}$ Another strategy would be to deny Heidegger's view of the embedded self and endorse a more neo-Kantian approach to law. ${ }^{47}$ Other strategies involve various forms of embrace of this exposure of the contingency of norms. ${ }^{48} \mathrm{My}$ aim in this paper is not to catalogue possible responses but to suggest another alternative largely absent in the literature. In the next major section, I will outline why I think that the work of Levinas provides legal theory with a distinct and important response to Heidegger's “norm anxiety.” As I will show, Levinas argues that there is a significance to the human beyond one's historical rootedness and which permits him to revive the centrality of justice in human society. At the same time, Levinas' revisioning of Heidegger does not require that we completely jettison Heidegger's insights into the socially embedded nature of the self.

\section{Levinas' Response to Heidegger's Norm Anxiety}

\footnotetext{
${ }^{46}$ See e.g., Rorty supra note 42.

${ }^{47}$ See e.g., Weinrib supra note 6 for an account of the private law that is heavily indebted to an understanding of Kantian agency.

${ }^{48}$ Supra note 3.
} 
As Adriaan Peperzak points out, early in his career Levinas had a deep admiration for Heidegger. ${ }^{49}$ Even as he became more critical of Heidegger's work, he was deeply influenced by it and remained, in a sense, in conversation with it. The following section primarily focuses on Levinas' first major work, Totality and Infinity, and the ways in which it provides a response to Heidegger's Being and Time ${ }^{50}$ Reference will be made to his other works as well, although a discussion of the reasons for some of the shifts in this work from early to later is beyond the scope of the argument presented here. ${ }^{51}$ What I will show is that Levinas does not dismiss Heidegger's account of the socially embedded self but rather shows that it is dependent upon what he calls the ethical relation-a relation to the other person. I will argue that the ethical relation provides Levinas with a sense of the human that does not wholly depend upon a particular historical or cultural context. Indeed, this is why Levinas himself admits to an affinity with the practical philosophy of Kant. ${ }^{52}$ As he writes: "If one had the right to retain a single feature of a

\footnotetext{
${ }^{49}$ Adriaan Peperzak, To the Other: An Introduction to the Philosophy of Emmanuel Levinas (West Lafayette, Indiana: Purdue University Press, 1993).

${ }^{50}$ Emmanuel Levinas, Totality and Infinity. trans. by Alphonso Lingis (Pittsburgh: Duquesne University Press, 1969)

${ }^{51}$ This paper primarily focuses on Totality and Infinity and not its relationship with Levinas' later major work, Otherwise than Being or Beyond Essence, trans. by Alphonso Lingis. (Pittsburgh, Pennsylvania: Duquesne University Press, 1981.) Otherwise than Being deals with many of the same themes as Totality and Infinity and is widely held to be Levinas' response to Derrida's criticisms in "Violence and Metaphysics" in Writing and Difference, trans. by A. Bass (Chicago: University of Chicago Press, 1978). This relationship is beyond the scope of the present work. However, Bernasconi helpfully describes one element of this shift in the following terms. For the later Levinas, he argues "I am radically responsible for the other prior to any contact, prior to having chosen or acted, indeed prior to my taking up a subject position in relation to an other. In Otherwise that Being the responsibility inherent in subjectivity is prior to my encounter with an other, whereas Totality and Infinity had located the possibility of ethics in the concrete encounter that realized the formal structure of transcendence." Robert Bernasconi, "What is the Question to Which 'Substitution' is the Answer?" in Simon Critchley and Robert Bernasconi, eds., The Cambridge Companion to Levinas (Cambridge: Cambridge University Press, 2002) at 242.

${ }^{52}$ Levinas, "Is Ontology Fundamental?" in Basic Philosophical Writings, Adriaan T. Peperzak, Simon Critchley and Robert Bernasconi, eds. (Bloomington: Indiana University Press, 1996) at 10.
} 
philosophic system while neglecting the details of its architecture...we would evoke Kant here: to find a sense to the human without measuring it by ontology[.]"53

The task of outlining a "Levinasian" account of legal norms is to delineate the relationship between the ethical relation and the sphere of justice. Levinas himself does not treat the question of justice in any detail and, as I will outline, some of the statements that he does make are unclear or even implausible. Nonetheless, I will argue that the basic terms of his engagement with Heidegger provide the basis upon which to construct a Leviansian account of liberal legal norms, and legal reasoning about those norms that provides a compelling response to Heideggerian norm anxiety.

\section{(a) The Self, the Other and the Third}

One way to cast Levinas' critique of Heidegger is to say that Heidegger does not understand the significance of the relation between the self and other people. As the previous section outlined, for the early Heidegger, there is the self (Dasein) and the social world of the public sphere. Language and the social world are part of our inescapable backdrop, and may be useful to many of our everyday concerns, but the project of individuation is one that requires us to "separate" from this sphere to become an "I." In contrast, for Levinas the question is not simply how we are to be a distinct and unique self in relation to the social sphere. His starting point deals with the relation between the self and another individual. This is, for Levinas, the ethical relation and his initial question is how these two terms may nonetheless be related in a manner that preserves

\footnotetext{
${ }^{53}$ Emmanuel Levinas, "Humanism and An-Archy" in Humanism of the Other trans. by Nidra Poller (Urbana and Chicago: University of Illinois Press, 2003) at 57.
} 
their uniqueness. He then asks what it means to have an account of the social sphere. As this section will outline, this starting point in terms of the relation between the self and the other, rather than on the relation between the self and the broader community, permits him to make a radical break with Heidegger.

For Levinas, our encounter with another individual is fundamentally different from our encounter with things in the world. While practical engagement within an already given context of meaning might indeed characterize my primary relation with a thing such as a hammer, it does not characterize my relation to another person. As Levinas argues, somewhat cryptically:

The person with whom I am in relation I call being, but in so calling him, I call to him. I do not only think that he is, I speak to him. He is my partner in the heart of a relation which ought only have made him present to me. I have spoken to him, that is to say, I have neglected the universal being that he incarnates in order to remain with the particular being he is. ...

A human being is the sole being which I am unable to encounter without expressing this very encounter to him. It is precisely in this that the encounter distinguishes itself from knowledge. In every attitude in regard to the human there is a greeting - if only in the refusal of greeting. Here perception is not projected toward a horizon[.. $]^{54}$

What he means is that when we face the other in conversation, the particularity of the individual is not comprehended from within a prior context of meaningfulness. Despite initially approaching another from within such a horizon of comprehension, to greet her is to attend to her particularity. Moreover, in conversation I speak to a particular other but the other also speaks and in doing so may contest whatever meaning I may purport to have of him. ${ }^{55}$

\footnotetext{
${ }^{54}$ Emmanuel Levinas, "Is Ontology Fundamental?" supra note 52 at 6-7. Emphasis added.

${ }^{55}$ Levinas, Totality and Infinity, supra note 50 at 195.
} 
The relation between the self and another is therefore not primarily conceptual, dependent upon a horizon of meaningfulness. ${ }^{56}$ Instead, the ethical relation is based upon language understood in terms of conversation. Moreover, what this analysis of conversation reveals is the radical alterity of the other person who cannot be captured by thematization, who "upsurges inevitably behind the said.,"57

Three important considerations follow from this view of the primary relation between the self and other, or what Levinas calls the ethical relation. First, this relation is asymmetrical. If it were reciprocal, then the other person could in fact be understood in terms of the self — as another self — which would erase the absolute alterity of the other person.

Second, in this relationship understood in terms of conversation, the other person does not just contest any meaning I might seek to give him. Importantly, he also calls me into question. As Robert Gibbs outlines:

Despite the semblance, the face is not itself the other person's face, but is a facing by the other, a being questioned or called to account for myself. Although I try to maintain myself as the center of that story, my orientation to others is making sense of them in my story; when I am confronted by another, why I am faced by another, I discern that my way in the world violated what was other about the others, what did not fit into my story. I have truncated and dislocated others, and so my desire to keep control of my world is now put in question. ${ }^{58}$

Thus in facing me, the other person calls me into question; I am called to justify myself to the other. ${ }^{59}$ Nonetheless, this encounter is not violent, "[f]or instead of offending my

\footnotetext{
${ }^{56}$ If it were, then this relation could be fully explicated through concepts which would then "undo" the absolute alterity that Levinas insists is at the heart of the relation.

57 Ibid.

${ }^{58}$ Robert Gibbs, "Philosophy and Law: Questioning Justice" in Edith Wyschogrod and Gerald P. McKenny, eds., The Ethical (Malden, MA: Blackwell Publishing, 2003) at 109.

${ }^{59}$ Ibid. at 40 .
} 
freedom it calls it to responsibility and founds it. ${ }^{60}$ In being faced, I am called to respond, which is why this relation is, for Levinas, a relation of ethical responsibility.

Third, this responsibility also "founds" the freedom of the "I". This theme of the uniqueness of the I as constituted in responsibility is something that Levinas develops at much greater length in his later works and the details of the shift are not important here. ${ }^{61}$ As he later asserts, "I am I in the sole measure that I am responsible, a noninterchangeable I... Such is my inalienable identity of subject." ${ }^{12}$ In other words, in responsibility I am unique and irreplaceable, and so properly constituted as a subject.

In this way, Levinas' view of the primacy of the ethical relation creates a radical shift away from Heidegger's understanding of the inescapable embeddedness of Dasein. For Levinas, the very subjectivity of the self is not essentially constituted in relation to a pre-given context of meaning but in relation to another person whom one approaches in conversation. Becoming a self is not an individual project of authenticity but is instead social at its core: I am only an "I" in relation to another. This individuation does not result from Heidegger's silent call of conscience, summoning the self out of its tangled absorption in the public realm, but from the address of the other who calls me to a responsibility that singles me out as unique.

\footnotetext{
${ }^{60} \mathrm{Ibid}$. at 203-4.

${ }^{61}$ In addition to this language of founding freedom, in Totality and Infinity, supra note 50 at 170-171, Levinas stresses the role of the Other in constituting the Same in terms of freeing it of its possession, and thereby its engagement in the non-I, in order to give what is possessed to the Other. See also p. 305: " to produce oneself as I-is to apprehend oneself with the same gesture that already turns toward the exterior...to respond for what it apprehends... it is to affirm that the becoming-conscious is already language, that the essence of language is goodness, or again, that the essence of language is friendship and hospitality." Nonetheless, as Diane Perpich points out, this theme is much clearer in Levinas' later work, Otherwise Than Being, but is present in Totality and Infinity as well. See Diane Perpich, "A Singular Justice: Ethics and Politics Between Levinas and Derrida" (1998) 42 Philosophy Today 59 at 64-65. ${ }^{62}$ Emmanuel Levinas, Ethics and Infinity: Conversations with Philippe Nemo, trans. by Richard A. Cohen (Pittsburgh: Duquesne University Press, 1985) at 101.
} 
At the same time, Levinas' account of a self constituted through responsibility to the other does not imply a rejection of the view that this self is also socially embedded within a particular historical context. What it argues for instead is that the self becomes a self primarily in ethical responsibility rather than in relation to its pre-given cultural understanding. As Diane Perpich argues, we can reconstruct Levinas' argument in the following way: "I do not meet the other in the world, rather to have a world (which means being capable of reflection) is already to be in a relationship to the other." ${ }^{, 63}$

Nonetheless, this sense of a significance to being human beyond one's particular context does not, on its own, provide the basis for norms and justice. For this, Levinas requires the social sphere In addition to the particular other, the self is also in relation to what Levinas calls the "third", or the all the other others. As Levinas explains,

[w]e are not a pair, alone in the world, but at least three. Two plus a third. If I heed the second person to the end, if I accede absolutely to his request, I risk, by this very fact doing a disservice to the third one, who is also my other. But if I listen to the third, I run the risk of wronging the second one. This is where the State steps in. The State begins as soon as three are present. It is inevitable. Because no one should be neglected, yet it is impossible to establish with the multiplicity of humanity a relation of unique to unique, of face to face. One steps out of the register of charity between individuals to enter the political. ... Without justice or the State, charity runs the risk of being wrong. However, it is clear that from the point of view of justice, preference for the other is no longer possible. ${ }^{64}$

In other words, the third introduces the social world and leads to the need for justice, institutions, and rights. ${ }^{65}$

The question then is: what kind of understanding of justice can proceed from this idea of thirds and what is its relationship to the ethical relation? The next section will

\footnotetext{
${ }^{63}$ Diane Perpich, The Ethics of Emmanuel Levinas (Stanford: Stanford University Press, 2008) at $132 .$.

${ }^{64}$ Emmanuel Levinas, "In the Name of the Other," in Is it Righteous to Be? Interviews with Emmanuel Levinas, ed. Jill Robbins (Stanford: Stanford University Press, 2001) at 194.

${ }^{65}$ Emmanuel Levinas, "Dialogue on Thinking-of-the-Other" in Entre Nous: Thinking-of-the-Other, trans. by Michael B. Smith and Barbara Harshav. (New York: Columbia University Press, 1998) at 202-203.
} 
outline why justice, understood in terms of legal obligation, cannot be understood as a kind of imperfect ethical obligation. This will then inform the discussion of the following section, where I argue that legal obligation concerns the claims that the self can make on another rather than the claim that the other makes on the self. I will then show how this can be used to provide an account of many liberal legal norms.

\section{(b) The Relationship between Legal Obligation and Ethical Obligation}

Levinas' writings are quite thin and wanting on the details of the relationship between justice and the ethical relation. Although his statements regarding the third suggest that justice and ethics are distinct, he also alludes to a complex relationship between them. For example, Levinas writes of a justice that is "always to be made more knowing in the name, the memory, of the original kindness of man toward his other ... A justice always to be perfected against its own harshness." 66 This "original kindness" is the ethical relation. Consider also the following description of the institutions of justice themselves:

legislation always unfinished, always resumed, a legislation open to the better. It attests to an ethical excellence and its origin in kindness from which, however, it is distanced - always a bit less perhaps - by the necessary calculations imposed by a multiple sociality, calculations constantly starting over again. Thus, in the empirical life of the good under the freedom of revisions, there would be a progress of reason. A bad conscience of justice! It knows it is not as just as the kindness that instigates it is good. But when it forgets that, it risks sinking into a totalitarian and Stalinist regime, and losing, in ideological deductions, the gift of inventing new forms of human coexistence. ${ }^{67}$

\footnotetext{
${ }^{66}$ Emmanuel Levinas, "The Other, Utopia, and Justice," in Entre Nous: Thinking-of-the-Other, trans. by Michael B. Smith and Barbara Harshav. (New York: Columbia University Press, 1998) at 229.

${ }^{67} \mathrm{Ibid}$. at 230.
} 
Justice is therefore an ongoing project of perfection, not in the name of universal reason, but motivated by a "bad conscience" that knows of its harshness with respect to the other.

The difficulty lies in understanding what these enigmatic suggestions mean in terms of the role the ethical relation is to play in relation to our concrete reasoning about the norms of justice. This difficulty is compounded by Levinas' very general use of the term "justice" which is invoked to refer to ideas as diverse as political institutions, economic arrangements and the law. I want to focus specifically on the idea of justice understood in terms of legal obligation and I want to reject the view that what Levinas is arguing for is a view of legal norms that must always be interrupted and displaced by reference to ethical obligation.

If legal norms are to be perfected through reference to the ethical obligation, then the relationship of law to ethics is of the imperfect to the ideal: legal obligation should become more like ethical obligation. For example, the argument would be that because we are ethically responsible to all others, the law steps in to limit this responsibility because it is impossible to meet. On such a view, legal obligation becomes a kind of truncated ethical obligation. Truncated because the law recognizes that we cannot respond to everyone, and so limits our obligation and ethical because ethical obligation nonetheless remains the starting point, and a kind of ideal. The most recent expression of this view is in Desmond Manderson's work, where the ethical ("proximity" in Levinas' later work) directly informs what our tort obligations should be. ${ }^{68}$

Another version of this view that legal norms are to be perfected through reference to ethical obligation is well expressed by Derrida:

\footnotetext{
${ }^{68}$ Desmond Manderson, Proximity, Levinas, and the Soul of Law (Montreal \& Kingston: McGill-Queen's University Press, 2006).
} 
Ethics enjoins a politics and a law: this dependence and the direction of this conditional derivation are as irreversible as they are unconditional. But the political or juridical content that is thus assigned remains undetermined, still to be determined beyond knowledge, beyond all presentation, all concepts, all possible intuition, in a singular way, in the speech and the responsibility taken by each person, in each situation, and on the basis of an analysis that is each time unique. $^{69}$

The content of the law is undetermined because this is the way that law remains "open" to the ethical. If the ethical relation is an "ideal" that keeps justice from lapsing into violence, then justice can never be thematized and must be constantly rescued from such thematization.

However, there are a number of important reasons why legal obligation should not be understood as a kind of imperfect ethical obligation in relation to which the ethical nonetheless functions as an unthematizable "ideal." One is the striking similarity between this view, at least on the second articulation outlined above, and the Heideggerian account of norms previously outlined. For, although Levinas rescues the significance of norms from Heidegger's problematic public realm, if they are to be understood as essentially and always contested, with no particular content required or rejected, then it is not clear how we could ever endorse liberal-democratic norms over other norms or develop an external critique of any choice of norms in a judicial context. Moreover, Levinas himself agrees that justice is not simply an imperfect form of ethical obligation or a kind of "degradation" or "limitation" of ethical responsibility. ${ }^{70}$ But most importantly, the idea that law is an imperfect form of ethical obligation profoundly misunderstands the nature of law. The rest of this section elaborates upon this.

\footnotetext{
${ }^{69}$ Jaques Derrida, Adieu to Emmanuel Levinas, trans. by Pascale-Anne Brault and Michael Naas (Stanford: Stanford University Press, 1999) at 115-6.

${ }^{70}$ Levinas, Otherwise Than Being, supra note 51 at 159.
} 
It is fairly uncontroversial to claim that in order to be called law, laws must be of general application. This means that laws must be universalizable. This does not mean that legal obligations imply reciprocal obligations. We can indeed conceive of an obligation that is universal even while asymmetrical. For example, parents have obligations towards children that are not reciprocal. In Levinasian terms, the kind of universal claim to derive from the ethical relation would be that each and every "I" (rather than "me") is infinitely responsible to an other. But, as Ciaramelli helpfully argues, the nature of ethical responsibility eludes this kind of generalization:

[e]ven if there is a universality of the ethical by virtue of the fact that each subject is called to a responsibility as infinite as mine, it is only from the perspective of my own assignation and election that I can put it into words. My own particular situation remains nonreciprocal and my position cannot be generalized. ${ }^{71}$

In this way, asymmetrical ethical obligation cannot be captured by the kind of rational discourse and thematization that is the life of the law: only the "I" but not the "me" is universalizable, but it is precisely the perspective of the "me" that is at issue in the ethical relation. The very idea of universalizing the position of the "me" into the position of the "I" is problematic, from the perspective of preserving the nature of Levinasian ethical responsibility.

Even if we could get around this difficulty, there is the more important problem of who could bring a claim that another has evaded their obligation. Consider a private law tort action and what this would entail if we were to think about it in terms of ethical responsibility. A legal claim consists in the plaintiff claiming that the defendant violated some duty owed to her. If this duty is understood in terms of Levinas' notion of ethical

\footnotetext{
${ }^{71}$ Fabio Ciaramelli, "Levinas's Ethical Discourse Between Individuation and Universality" in Robert Bernasconi and Simon Critchley, eds., Re-Reading Levinas (Bloomington and Indianapolis: Indiana University Press, 1991) at 92.
} 
obligation, then the plaintiff's claim is that the defendant failed to meet his or her ethical responsibility to her. This might be tempered, and limited, by any number of practical considerations, but this would be the basic form of the claim. The problem with such a claim is twofold. ${ }^{72}$ First, in the very making of this claim, the plaintiff steps out of the register of ethics. Levinas is clear that another claiming that I am responsible to them is the contrary of what he is talking about: "[i]mmorality begins when we start saying that someone must substitute him or herself for me."73 Ethics is concerned with the responsibility that I have for another - it is one-directional, from me to the other, fundamentally asymmetrical. The fact that the other might have responsibility for me is simply his own affair, never mine. ${ }^{74}$ The legal claim described can therefore never be made by an "other," but is always made by an "I" and this makes it fundamentally an egoist claim, not an ethical one. Moreover, if we try to mitigate this through claiming that everyone is entitled to make such a claim of another, then all asymmetry is lost.

From the standpoint of Levinasian ethics, therefore, the defendant might indeed be in a relationship of ethical responsibility towards the plaintiff but the plaintiff simply cannot make this claim as an ethical claim, even an imperfect one.

This, of course, does not mean that the "I" can never claim that another has violated some duty owed. But it does mean that this claim lies in the realm of justice, understood to be essentially distinct from ethics and not as an imperfect form of ethics. Indeed, Levinas argues that both justice and ethics are required in order to "suppress

\footnotetext{
${ }^{72}$ There is actually another difficult. Levinas always stressed the "infinite" nature of ethical responsibility-it's nature is that is cannot ever be fulfilled, there is always a surplus of duty. Transformed into legal obligation, this would mean that the defendant is always open to liability no matter what her actions, and this makes action per se wrong. This would be an absurd conclusion.

${ }^{73}$ Emmanuel Levinas, De Dieu qui vient à l'idée (Paris: Vrin, 1982) at 135. As cited in Ciaramelli, supra note 71 at 92 .

${ }^{74}$ Emmanuel Levinas, Ethics and Infinity, supra note 62 at 98.
} 
violence" for, if left to themselves they would lead to their contrary. ${ }^{75}$ If justice and ethics each requires the other in order to not lapse into violence, then they must be understood as distinct realms. A world where the "I" can never make a claim on another, let alone demand its enforcement, is clearly a world that risks violence. There is nothing in Levinas' analysis of the ethical relation that implies that people will and do in fact act in accordance with this responsibility. Levinas argues that it claims us prior to any choice on our part, but this does not mean that we will in fact choose to act in a manner that is for-the-other. ${ }^{76}$ Indeed, Levinas argues that "the Other is the sole being I can wish to kill." ${ }^{, 77}$ Justice is required to both prevent this and to provide redress. ${ }^{78}$

For these reasons - that the ethical resists universalization, reciprocity, claims made by an "I", and conflation with justice-we can argue that although ethics demands law, this cannot be a demand that the law be ethical, even in a limited way. If this is so, then what is the nature of the relationship between legal obligation and ethical obligation? This question is taken up in the next section. The solution that I suggest lies in understanding that Levinas' logic of thirds does indeed demand norms such as dignity and equality as well as a certain understanding of the way in which we reason about such norms.

\footnotetext{
${ }^{75}$ Emmanuel Levinas, “Transcendence and Height” in Adriaan T. Peperzak, Simon Critchley, and Robert Bernasconi, eds., Basic Philosophical Writings (Bloomington and Indianapolis: Indiana University Press, 1996) at 24.

${ }^{76}$ In Otherwise than Being, Levinas is clearer regarding the way in which ethical responsibility constitutes the subject as subject and so is prior to any idea such as action and choice. As Diane Perpich writes, "Being for-the-other is the pre-condition for all other subject experiences." See The Ethics of Emmanual Levinas supra note 63 at 130.

${ }^{77}$ Levinas, Totality and Infinity, supra note 50 at 198.

${ }^{78}$ Levinas is not as clear with respect to why ethics requires justice as he is with respect to why justice requires ethics and there are a number of different interpretations. See William Paul Simmons, "The Third: Levinas' theoretical move from an-archical ethics to the realm of justice and politics" (1999) 25 Philosophy \& Social Criticism 83 at 95-96 and 98 for an interpretation that is similar to mine. See also Perpich, "A Singular Justice" supra note 61 at 62 for a discussion of Derrida's reading of the risk of ethics being a kind of "vertigo" in which the relation with the Other collapses "into a solipsism which is no longer capable of distinguishing I from Other, justice from injustice.”
} 


\section{(c) The Question of Norms and the Logic of Thirds}

In my view, the key to understanding what a Levinasian account of legal norms would look like lies in further unpacking his view of the third. The third is another other, in relation to me and to others in return. In this way, the third introduces a plurality of ethical relationships which defy conceptualization. For Levinas, this means that we need to rethink the social realm in a manner that can preserve this plurality. As he outlines:

Neither a simple addition of individuals belonging to the extension of a concept, nor a configuration of moments constituting or realizing the comprehension of the concept man, the totality cannot be reduced to a kingdom of ends.... The totality, insofar as it implies multiplicity, is not established between reasons, but between substantial beings who are capable of maintaining relationships. What can this relationship be, since no conceptual link exists prior to this multiplicity? And what can injustice or justice mean in this relationship when individuals ... do not have the unity of a concept, and when the standard of justice cannot be obtained by simply comparing individuals? The totality rests on a relationship between individuals, other than the respect of reason. ${ }^{79}$

In other words, the sociality brought about by the third, which founds justice, cannot be fully captured through reason. The puzzle is to understand what it means to have a social realm whose significance cannot be characterized in the familiar terms of reason but which "rests on a relationship between individuals." This in turn is not to be understood simply in terms of "comparing individuals" but, as Levinas puts it elsewhere, demands we compare "the incomparable." 80

This language of comparing what is incomparable can easily lead to the view that justice asks me to compare the claims of the other who faces me as well as all others in

\footnotetext{
${ }^{79}$ Emmanuel Levinas, "The I and the Totality," in Entre Nous: Thinking-of-the-Other, trans. Michael B. Smith and Barbara Harshav (New York: Columbia University Press, 1998) at 27.

${ }^{80}$ Emmanuel Leivnas, Ethics and Infinity, supra note 62 at 90.
} 
the social realm. However, as I already argued, legal norms cannot be undersood in tersm of comparing the claims of various "others." Legal claims are not about the "me" who is faced with competing claims and the need to adjudicate between these, but about the "I" who can justifiably make a claim on another.

Because of this, it is important to take seriously Levinas' statements regarding the nature of human rights and their relation to the ethical. To be sure, Levinas emphasizes the role of the other in legitimating human rights. But it is crucial to understand that the role of the other is the role of constituting the unique subjectivity of the "I" who can be the rights-bearer. Levinas does argue that human rights are first the rights of the other person - to the "I" they arise as obligation. But it is this obligation that then affirms the rights of the "I" by affirming the freedom of the I: for in responsibility "I am chosen as unique and incomparable." ${ }^{\text {81 }}$ And: "My freedom and my rights, before manifesting themselves in my opposition to the freedom and rights of the other person, will manifest themselves precisely in the form of responsibility, in human fraternity." ${ }^{\prime 82}$ For Levinas, therefore, the "I" who can make a rights-claim is an "I" produced initially through responsibility, a responsibility that affirms the "I" as unique and incomparable and provides the condition for concern regarding the rights of the other.

These comments must be kept in mind when interpreting other statements by Levinas that are more ambiguous. For example, he writes:

The rights claimed under the title rights of man, in the rigorous and almost technical sense which that expression has taken on since the eighteenth century-

\footnotetext{
${ }^{81}$ Emmanuel Levinas, "The Rights of Man and the Rights of the Other" in Outside the Subject, trans. by Michael B. Smith (Stanford, California: Stanford University Press, 1994) at 125. See also "The Rights of Man and Good Will" in Entre Nous: Thinking-of-the-Other, trans. by Michael B. Smith and Barbara Harshav (New York: Columbia University Press, 1998) and "The Rights of the Other Man" in Alterity \& Transcendence, trans. by Michael B. Smith (New York: Columbia University Press, 1999).

${ }^{82}$ Ibid. at 125.
} 
the right to respect for the human dignity of the individual, the rights to life, liberty, and equality before the law for all men - are based on an original sense of the right, or the sense of an original right. ... For today's way of thinking, these rights are more legitimate than any legislation, more just than any justification. They are probably, however complex their application to legal phenomena might be, the measure of all law and, no doubt, of its ethics. ${ }^{83}$

This quote is misleading if we read it to indicate that the justice of the law is measured by the degree to which it is ethical. The other way to understand it is in the sense just outlined: law requires the ability of the "I" to make a claim on another. But for Levinas, this "I" must be understood to arise through responsibility, not freedom. It is in this sense that rights retain their connection to ethics.

The relationship of justice is one that is about freedom, not responsibility; it is about the relationship between "I's" and not between me and the other. Indeed, Levinas offers a very Kantian notion of justice as “the right of man's free will and its agreement with the free will of the other." ${ }^{, 84}$ Nonetheless, for Levinas, rights are not to be understood in terms of a reciprocity between individuals who are all affirmed to be essentially the same. Instead, my freedom as an "I" depends upon a prior ethical responsibility that claims me as unique and irreplaceable and therefore incomparable. Moreover, my concern for the rights of the other "I's" with whom I am in relation is a concern that is not primarily founded in the demands of an abstract universal reason, but in the demands of the other that constitutes me as a self.

This interpretation is also consistent with Levinas' statements regarding justice in his second major work, Otherwise Than Being. He argues:

\footnotetext{
${ }^{83} \mathrm{Ibid}$. at 116 , emphasis added.

${ }^{84}$ However, despite the many ways in which Levinas both implicitly and explicitly distances himself from Kant, he admits that the sphere of relations following from his analysis of the ethical relation, although only "glimpsed" at in his work, seems close to the practical philosophy of Kant. Levinas, "Is Ontology Fundamental?" supra note 54 at 10.
} 
Justice can be established only if I, always evaded from the concept of the ego....always in non-reciprocatable relationship with the other, always for the other, can become an other like the others. ...My lot is important. But it is still out of my responsibility that my salvation has meaning[.] ${ }^{85}$

Justice is not about weighing the claims of all the others as a kind of "limitation of anarchic responsibility" but the way in which the "I" gets included and can make claims regarding how it is treated by others. ${ }^{86}$ The comparison of incomparables must therefore involve comparing the claims of subjects.

Levinas' writings on the nature of human rights not only show us that justice is about the claims that the self can make of another, they show us that a Levinasian account of justice has a strong affinity with liberal-democratic legal norms. It is not simply human rights discourse that Levinas can endorse. As already discussed, justice is about the relationship between "I's" understood in terms of freedom. But the peculiar logic of the comparison of incomparables implies two other norms: equality and dignity. If we do not posit a basic equality between persons, then it is difficult to see how we should be concerned to compare the claims of individuals rather than simply prefer one over the other without a need to justify this preference. Moreover, the manner in which persons can be said to be incomparable is not for Levinas a reference to the particularities of each person - their skin colour, gender, personal histories, cultural background, etc.but the idea of the self that is constituted as unique through responsibility. This idea is not well-captured through the idea of difference but rather through the idea of an absolute dignity of persons that cannot be thematized. It is not that individuals are the same in their dignity, for this idea — dignity—is itself a kind of signification of the absolute

\footnotetext{
${ }^{85}$ Supra note 51 at 160-161.

${ }^{86} \mathrm{Ibid}$. at 159.
} 
singularity of the self. But we can say that in their dignity, individuals are equal even if not the same.

If the comparison of incomparables can lead to the endorsement of liberaldemocratic legal norms such as freedom, equality and dignity, it also demands resistance to the thematization of rational discourse. Indeed, if we take seriously Levinas' views regarding the radical plurality of the social sphere then the norms of justice can never form what he deplores as a "unity of concept." $" 87$ This suggests, in opposition to reasoning about norms, an attentiveness to the particularities of specific rights-claims made by a rights-claimant who is unique and incomparable. How can both be true? How can we claim to both endorse general - even universal — norms and at the same time undercut this through a suspicion of reason and an appeal to particularity and plurality?

This can be rendered less paradoxical if we shift from thinking about norms to thinking about the practice of reasoning about norms. For example, in an interview Levinas discussing justice argues

the Talmud never limits itself to the concept, which, however, is important to it. When it uses concepts, it never forgets the example from which the concept was drawn. "Here is the law-it is perfectly good, but what will happen if ..." This "what will happen if ..." is a particular case. The discussion never drops it, and often the concept is reversed and reveals a completely different meaning than the one it "pretended to be" at the beginning. ${ }^{88}$

Here we have an example of reasoning which, although making use of reason and concepts, nonetheless is limited through a constant reference to the particular case that itself tempers the operation of the concept at issue. Particular cases always provide a kind of limitation of the category. The significance of this, for a Levinasian view, is not in the

\footnotetext{
${ }^{87}$ Supra note 79.

${ }^{88}$ Levinas, "Dialogue on Thinking-of-the-Other" in Entre Nous: Thinking-of-the-Other, trans. by Michael B. Smith and Barbara Harshav (New York: Columbia University Press, 1998) at 204.
} 
way that particulars help to sharpen the contours of the principle already latent in the law, but the way it permits the law to retain its connection to the essential dignity of man, which can never be fully thematized even as it demands thematization. The particular case has a normative primacy over the concepts with which the case might be categorized. At the same time, the significance of the particular case is not in the factual particulars per se but the way in which this permits the law to honour rather than erase the absolute incomparability of each. In other words, the particular takes precedence over principle but only in the name of that which "founds" the need for the principle in the first place — the unique and incomparable self.

Indeed, this manner in which the law honours the singularity of the human through an emphasis on the particular case also connects to Levinas' endorsement of human rights as the measure of the justness of a legal system. Human rights also assert the significance of the individual against the collective. Levinas is therefore concerned with this theme at both the level of the norm as well as at the level of how we reason about these norms.

This account of the primacy of the particular case over the general principle can also provide a more plausible account of the relationship between verdict and afterverdict that Levinas himself suggests. In a comment on a Talmudic text, Levinas indicates that the relationship between justice and the ethical relation can be illustrated through the combination of verdict and after-verdict. The verdict given is dictated by strict impartiality, whereas the after-verdict allows for the possibilities of charity and mercy while still not contradicting the verdict. This space for charity is not something that Levinas sees as essentially separate from justice. As he argues, "[t]his after-verdict, 
with its possibilities of mercy, still fully belongs - with full legitimacy - to the work of justice." ${ }^{89}$ However, it is implausible to suggest that the judge, in facing the accused and determining a sentence is engaged in "charity" in a manner that can be understood in terms of the ethical relation between the judge and the accused. First, this ignores the violence inherent in sentencing. ${ }^{90}$ Second, although sentencing generally involves a great deal of discretion, it is not the case that the judge simply faces the accused, freed of the demands of impartiality, and able to respond ethically. Even in sentencing a judge must still take into account societal interests and policy goals, as well as concerns of fairness between similarly situated accused. A better account of the discretion inherent in sentencing is that this is one of the ways in which the law ensures that there is a place for the particular to take precedence over the principle. ${ }^{91}$

Even if the judge rendering judgment is never simply faced with the accused and must always take into account other interests, this does not mean that the ethical relation between the judge and the accused is irrelevant. Levinas views it as crucial to maintain a space for the individual consciences of those involved in the administration of justice, who can maintain a sense of the way in which they are always under a surplus of duty that they can never fulfill. As Levinas argues:

For me ... the element of violence in the State ... appears even when the [State] functions perfectly, when everyone submits to universal ideas. There are cruelties which are terrible because they proceed from the necessity of the reasonable Order. There are, if you like, the tears that a civil servant cannot see: the tears of the Other (Autrui)....In such a situation, individual consciences are necessary, for they alone are capable of seeing the violence that proceeds from the proper functioning of Reason itself. ... I alone can perceive the "secret tears" of the

\footnotetext{
${ }^{89}$ Emmanuel Levinas, "The Other, Utopia, and Justice," in Entre Nous: Thinking-of-the-Other, trans. Michael B. Smith and Barbara Harshav (New York: Columbia University Press, 1998) 231.

90 See e.g., Rober Cover, "Violence and the Word" (1986) 95 Yale L.J. 1601.

${ }^{91}$ Levinas' account of the relationship between verdict and after-verdict is more plausible in the context of pardons granted by the Crown.
} 
Other, which are caused by the functioning — albeit reasonable — of the hierarchy. ${ }^{92}$

The law must therefore preserve a place for the individual conscience that can perceive the "tears of the Other." On this reading, the "bad conscience" of the law, the motivating force that drives it toward revising itself, is the individual consciences of those involved in administering justice and the compassion and humanity that this engenders.

For these reasons, an important aspect of a Levinasian account of liberaldemocratic legal norms is that it would focus less on the abstract "logic" of these norms and more on the social practice of reasoning about these norms. But this idea is not necessarily foreign to the law as we know it. The idea of a social practice of reasoning could also describe — and justify_common law reasoning, if certain features are emphasized. In a common law system of adjudication, the development of legal norms proceeds on a case-by-case basis. However, this is not on an ad hoc basis, for the demands of precedent constrain adjudicators to decide like cases alike. Nonetheless, in comparing particular cases to determine whether they indeed are alike, cases are always distinguished, and limited, according to the facts in a way that could be described as giving the particular case a significance beyond any specific principle or principles that it may appear to stand for. Moreover, the common practices of reasoning by analogy, the frequent reinterpretation of past cases, the status given to dissenting judgments, and the occasional recognition that a case is sui generis all highlight the manner in which the common law could be said to recognize that a particular case can never be wholly contained within a category. At the same time, the practice of common law reasoning

\footnotetext{
${ }^{92}$ Emmanuel Levinas, "Transcendence and Height" in Adriaan T. Peperzak, Simon Critchley, and Robert Bernasconi, eds., Basic Philosophical Writings (Bloomington and Indianapolis: Indiana University Press, 1996) at 23.
} 
clearly recognizes the importance of principles and categories; an emphasis on the particular, in its rejection of total coherence, need not be an emphasis on incoherence.

While only briefly sketched here, such an account of common law reasoning would contrast sharply with a number of other theoretical accounts. For example, Ernest Weinrib's formalist position holds that "[t]he particularities of the events are legally relevant only inasmuch as they instantiate a category applicable to the legal relationship to which they give rise. ${ }^{.93}$ Moreover, his account emphasizes the "extreme tendency to abstract that marks legal thinking" as well as the claim that law is best understood as a "coherent justificatory enterprise." ${ }^{94}$ For Levinas, the ways in which the law actually falls short of such strong coherence is not to be understood in terms of a failure of aspiration but precisely as the manner in which justice is necessarily an unfinished project of perfection. Moreover, an essential aspect of the perfecting of the law comes about not through a reference to an idea of unity but precisely as the interruption of such purported unity in order to take account of the particular, in the name of an equality of dignity that can never by fully thematized even as it demands thematization.

For similar reasons, a Levinasian view of common law reasoning would contest the aspiration to the kind of strong coherence required, at least in principle, by Dworkin's account of the Herculean judge. ${ }^{95}$ For Dworkin, in deciding difficult cases a judge must take on the role of Hercules by taking into account legal principles already implicit in the law and providing an interpretation that has the best fit with these principles. Therefore what looks like the exercise of discretion, because a judge is not applying a settled

\footnotetext{
${ }^{93}$ Ernest J. Weinrib, "Correlativity, Personality, and the Emerging Consensus on Corrective Justice." (2001) 2 Theoretical Inquiries L. 107.

${ }_{94} \mathrm{Ibid}$. at 114.

${ }^{95}$ Ronald Dworkin, Law's Empire, supra note 2.
} 
meaning of a rule, is in fact an interpretive activity utilizing legal principles that can indeed yield a correct legal answer rather than one that opens the law to judicial politics. However, on a Levinasian account we could argue that the "gaps" for discretion that are found in the law are places that allow a needed connection to the particular, a recognition that the values of freedom, dignity and equality can never be fully captured in the expression of legal principles, not places where extra-legal considerations must be completely banned through an appeal to a strong sense of conceptual coherence. The interpretive flexibility of the law does not call into question the legitimacy of the law but in fact grounds its legitimacy so long as it does so in the name of further perfecting the universal norms of freedom, equality and dignity.

\section{Conclusions}

In this paper I have argued that the work of Emmanuel Levinas provides an important response to what I have been calling "norm anxiety." The reason that Levinas should be an interesting thinker for legal theorists is that his understanding of the ethical relation between the self and the other provides a direct response to Heidegger's sophisticated and influential account of the socially embedded self and the consequent historical contingency of any norms that follows from this account. As I outlined, Heidegger's account raises a number of serious tensions in relation to liberal-democratic legal norms. Levinas' response to Heidegger is not a retreat back to a more rationalist understanding of the self but rather asserts that even if we are socially embedded within a particular historical context, this is not all that we are. It is this "not all that we are" that 
opens up a unique response to norm anxiety, one that permits both the endorsement of liberal-democratic norms as well as an acknowledgment of the historical and cultural specificity of any particular articulation of these norms.

For Levinas, prior to all context, we are constituted by a relation to the other who calls us to responsibility. This understanding of the significance of the human that lies outside all culture and history can provide the basis for affirming a number of liberaldemocratic legal norms, although not in the straightforward sense where Levinasian ethical responsibility becomes the basis of legal responsibility. I have argued that legal responsibility, as a form of justice, is about the claims that a self can make on others, not about the claims that the other, and the other others, make on the self. These claims are based on freedom, not responsibility, although it is the freedom of a self who is constituted through responsibility. This unique and incomparable self that is the concern of justice "grounds" liberal-democratic norms such as freedom, equality and dignity. Importantly, this same idea of the self also demands the recognition of limits to any legal discourse regarding these norms. I have argued that this leads to an emphasis on the practice of reasoning about these norms, including a requirement that justice include a space for a focus on the particular case to take precedence over the theoretical articulation of a principle or principles. However, because the significance of the particular lies in its connection to the idea of the self, constituted in responsibility as unique and incomparable, a Levinasian emphasis on the particular does not leave us with the celebration of difference and particularity per se. As already outlined, it is this same idea of the self that provides the basis for endorsing particular liberal-democratic legal norms, 
such as freedom, equality, dignity and human rights and prevents the practice of legal reasoning from lapsing into incoherence.

Much would have to be done in developing such a view into a full account of law and legal reasoning. My claim here has been much more modest: to show why a Levinasian account of justice and legal obligation provides an interesting and distinct alternative to existing responses to "norm anxiety" and can be used as the basis for constructing an account of liberal-democratic legal norms. 